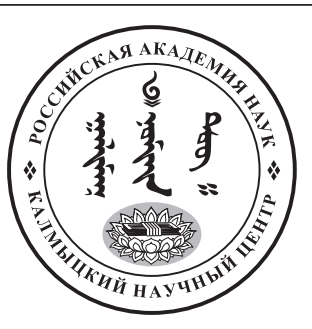

Published in the Russian Federation

Oriental Studies (Previous Name: Bulletin of the Kalmyk Institute

for Humanities of the Russian Academy of Sciences)

Has been issued as a journal since 2008

ISSN: 2619-0990; E-ISSN: 2619-1008

Vol. 14, Is. 3, pp. 459-468, 2021

Journal homepage: https://kigiran.elpub.ru

УДК / UDC 94(470.57)

DOI: $10.22162 / 2619-0990-2021-55-3-459-468$

\title{
Социальный статус женщины в семье Башкирии в первое десятилетие советской власти
}

\author{
Гульфия Юнировна Султангужина ${ }^{1}$
}

${ }^{1}$ Институт истории, языка и литературы Уфимского федерального исследовательского центра РАН (д. 71, пр. Октября, 450054 Уфа, Российская Федерация)

кандидат исторических наук, научный сотрудник

iD 0000-0003-2533-5045. E-mail: Gulfiyasultan@yandex.ru

\author{
(C) КалмНЦ РАН, 2021 \\ (С) Султангужина Г. Ю., 2021
}

Аннотация. Введение. В настоящей статье предпринята попытка осветить место и роль женщины в семье Башкирии в 1917-1927 гг. Цель исследования — на основе нового материала показать особенности семейного статуса женщины в 1920-е гг. Материаль и методы. Ocновными источниками стали документы Российского государственного архива социально-политической истории, Национального архива Республики Башкортостан. Большое значение в раскрытии темы сыграли опубликованные источники. В ходе исследования применялись статистический, описательный, сравнительно-исторический методы исследования. Результаты исследования показывают, что этот период был наполнен самоотверженной борьбой женщин за улучшение своего положения в различных сферах жизни и деятельности. Эта борьба была долгой и трудной. В Башкирии старый уклад жизни менялся медленно. В эти годы в Башкирии старые обычаи и нравы продолжали играть важную роль в регулировании семейно-брачных отношений. В частности многоженство, ранние браки, выдача замуж против воли девушек, калым и т. д. были обычным явлением. При этом первое десятилетие советской власти - это период, когда были достигнуты серьезные успехи в укреплении фактического равноправия женщины в семье. Законодательные мероприятия были направлены на повышение семейного статуса женщины. В рассматриваемый период положение женщины в семейно-бытовой сфере начинает меняться. В эти годы стал формироваться образ «новой женщины» в семье.

Ключевые слова: семейное законодательство, Башкирия, социальный статус женщины, равноправие, семья, пережитки старого быта

Благодарность. Исследование проведено в рамках государственной субсидии - проект «Духовная культура тюркских народов Южного Урала» (номер госрегистрации: AАAA-A17-117040350082-3).

Для цитирования: Султангужина Г. Ю. Социальный статус женщины в семье Башкирии в первое десятилетие советской власти // Oriental Studies. 2021. T. 14. № 3. С. 459-468. DOI: 10.22162/2619-0990-2021-55-3-459-468 


\title{
The Bashkir Woman's Social Status within the Family in the First Soviet Decade
}

\author{
Gulfiya Yu. Sultanguzhina ${ }^{1}$ \\ ${ }^{1}$ Institute of History, Language and Literature of the Ufa Federal Research Centre of the RAS \\ (71, Oktyabrya Ave., 450054 Ufa, Russian Federation) \\ Cand. Sc. (History), Research Associate
}

iD 0000-0003-2533-5045. E-mail: Gulfiyasultan@yandex.ru

(C) KalmSC RAS, 2021
(C) Sultanguzhina G. Yu., 2021

\begin{abstract}
Introduction. This article attempts a review of key trends in the transformation of Bashkir women's social status within the family framework between 1917 and 1927. Goals. The study employs newly discovered data to show some specific features in the marital status of Bashkiria's women in the 1920s. Materials and Methods. Relevant documents from the Russian State Archive of Social and Political History and the National Archive of the Republic of Bashkortostan served as the main sources for the research; published materials on the subject also proved as instrumental and efficient. The research methods employed include statistical, descriptive, and comparative historical ones. Results. The research indicates that the period under consideration was marked by the struggle of dedicated women to improve their positions in various spheres including that of the family. The struggle was long and painstaking. In Bashkiria, the old ways were changing slowly, and throughout those years traditional Bashkir customs and perceptions continued to play an important role in regulating family and marriage institutions. Such phenomena as polygamy, early marriages (including unwilled and unequal ones), kalym and others were still quite common. Nevertheless, the first decade of Soviet rule in the republic was also a period of serious success marked by advancing the de facto equality of women in the family, and the legislative measures did seek to improve the marital status of women. The analysis shows that in the period in question was witnessing a radical transformation in women's positions in the family and everyday life contexts. The research allows for a conclusion that the image of a 'new woman' in the family sphere was being shaped during the first Soviet decade. Keywords: family legislation, Bashkiria, the social status of women, equality, family, the vestiges of the old way of life
\end{abstract}

Acknowledgements. The reported study was funded by government subsidy — project name 'Turkic Peoples of the Southern Urals: Spiritual Culture' (state reg. no. AAAA-A17-117040350082-3).

For citation: Sultanguzhina G. Yu. The Bashkir Woman's Social Status within the Family in the First Soviet Decade. Oriental Studies. 2021. Vol. 14 (3): 459-468. (In Russ.). DOI: 10.22162/2619-09902021-55-3-459-468

\section{है}

\section{Введение}

В современном обществе женщины обладают равными юридическими правами с мужчинами. Однако, как отмечают специалисты (историки, социологи, демографы, психологи), в Башкирии дискриминация женщин продолжает существовать [Сулейманова 1998; Сулейманова 2008; Сулейманова 2013; Хилажева 2010; Хилажева 2015; и др.].
Многие проблемы в семье, которые стояли перед женщиной в 1920-е гг., актуальны и сегодня. Так, проблема насилия женщин в семье довольно часто освещается средствами массовой информации. Общественностью обсуждаются вопросы легализации многоженства, ранних браков. Споры по вопросу законодательного закрепления полигинии не утихают в парламенте Башкортостана протяжении последних 20 лет. Поэ- 
тому опыт борьбы за равноправие женщин в семье в первое десятилетие советской власти имеет неоценимое значение.

В свете требований современности исторический опыт нуждается в тщательном изучении и освещении. Данное исследование поможет использовать положительные результаты и учесть ошибки прошлого.

\section{Историография проблемы}

В советской историографии отсутствуют специальные исследования, посвященные этой теме. Все труды носили пропагандистский характер и давали общую характеристику положения женщин в СССР, региональный компонент зачастую затрагивается поверхностно [Зуева 1925; Намитоков 1929; Бильшай 1959; и др.]

Имеются отдельные работы, в которых рассматривалась деятельность государственных и партийных организаций по защите прав женщин [10 лет работы 1927; Стина 1928; Нухрат 1932; и др.]. Анализировались вопросы положения женщины у башкир, вскрывались проблемы женского равноправия и пути их решения [Женщины Башкирии 1968; Нафиков 1974].

Среди фундаментальных работ по женской истории особое место занимают работы Р. Н. Сулеймановой. В них на материале разнообразных источников рассматривается положение женщины в семье во второй половине прошлого века [Сулейманова 2014; Сулейманова, Исянгулов 2020; и др.].

Среди работ, затрагивающих эту тему, следует выделить также исследования [Сытник 2006; Градскова 2011; Мирошниченко 2015a; Мирошниченко 2015б; Журавлева, Мирошниченко 2017; Гниятуллина 2017].

Источниковую базу исследования составляют следующие виды документов: циркуляры, протоколы партийных конференций, резолюции конференций работниц и крестьянок, беспартийных женских конференций, доклады, отчеты женорганизаторов, отчеты женотделов, отчеты комиссии и т. д., извлеченные из архивохранилищ и из периодической печати. Документы представляют ценность в раскрытии политики государства в отношении женщины в семье. Особый интерес представляют деятельность судебных учреждений в сфере брака и семьи. Уникальность представляют документы личного происхождения - письма женщин, заявления активисток, воспоминания женработников [НА РБ. Ф. 122].

Закрепление нового правового статуса женщины в семье

Октябрьская революция 1917 г. ознаменовала собой коренные изменения в положении женщины в различных сферах жизни общества, в том числе в брачно-семейных отношениях. В центре внимания стояли вопросы предоставления женщине равных с мужчиной прав и свобод в организации семейной жизни. Уже первые советские декреты позволили не только очистить семейные отношения от отживших обычаев, которые часто ставили женщину в неравноправное положение в семье, но и установить демократические принципы построения семьи.

Декретом «О гражданском браке, о детях и о ведении книг актов состояния» от 18 декабря 1917 г. закреплено полное равноправие супругов в области семьи и брака. Устанавливалась моногамная форма брака, и был четко определен возраст брачующихся, закреплен принцип свободы и добровольности заключения брака между мужчиной и женщиной. Впредь законными признавались только гражданские браки, зарегистрированные в соответствующих государственных органах. Брак, совершенный по религиозным нормам после принятия декрета, терял юридическую силу. Большое значение имело формулирование декретом правил о правовом положении детей. В статье 10 декрета указывалось, что «дети внебрачные уравниваются с брачными относительно прав и обязанностей как родителей к детям, так и детей к родителям» [СУ РСФСР 1942 (1917a): № 11. Ст. 160].

Декрет «О расторжении брака» от 19 декабря 1917 г. сыграл в борьбе за равноправие женщин большую роль. Согласно этому декрету, процедура развода упрощалась. Декрет устанавливал, что брак расторгается по обоюдному согласию в отделе записей браков или по одностороннему - в суде [СУ РСФСР 1942 (1917б): № 10. СТ. 152].

Следующим этапом в совершенствовании законодательства о браке и семье явилось принятие 16 сентября 1918 г. Кодекса законов об актах гражданского состояния, брачном, семейном и опекунском праве. Семейный кодекс продолжил реализацию идеи, направленной на уравнение прав 
мужчины и женщины в семье. Тем не менее сохранялся режим раздельности супружеского имущества [СУ РСФСР 1942 (1918): № 76-77. СТ. 818].

Как впоследствии показало время, это привело к существенному ущемлению прав и интересов женщин, когда, будучи в браке, они не имели собственного заработка. В 1922 г. Высший судебный контроль Наркомата юстиции РСФСР, не разделяя такой подход, указал, что «при расторжении брака народный суд должен войти в обсуждение того, насколько по обстоятельствам дела был значителен труд, вкладывающийся женой за время супружества в общем хозяйстве» [Еженедельник 1922: 12].

Особенности быта некоторых автономных республик и областей РСФСР побудили ВЦИК РСФСР 16 октября 1924 г. внести изменения в нормы действовавшего уголовного законодательства. Установлена была уголовная ответственность за бытовые преступления, которые были включены отдельную главу кодекса. В нем были сформулированы такие составы преступлений, как многоженство, уплата и принятие выкупа за невесту, умыкание и т. д. [Постановление ВЦИК 1924].

1 января 1927 г. вступил в силу новый Кодекс законов о браке, семье и опеке (КзоБСО), который приравнивал незарегистрированные браки к бракам зарегистрированным. Доказательством наличия фактического брака являлись: совместное проживание, воспитание детей, ведение при этом общего быта и т. д. В эти годы существовало большое количество незарегистрированных браков в ЗАГСе. Поэтому признание юридической силы за фактическим браком было направлено на защиту прав женщин и имело чрезвычайно большое значение для них.

Кодексом РСФСР 1926 г. нажитое в браке имущество признавалось совместным имуществом супругов, что было выгодно для женщин. Кодекс упорядочил процедуру установления отцовства [Постановление ВЦИК 1926].

Большое значение имели некоторые изменения правовых форм борьбы с бытовой преступностью. 6 апреля 1928 г. ВЦИК принял постановление, которым были внесены дополнения в Уголовный кодекс РСФСР 1926 г. В систему уголовных наказаний введены меры ответственности в отношении лиц (ст. ст. 196-199 УК РСФСР), посягающих на свободу и равноправие женщины в семье [Постановление ВЦИК 1928].

Становление и развитие образа «новой женщины» в семье

Новые правовые нормы утверждались в Башкирии постепенно. В первую половину 1920-х гг. старые обычаи и нравы все еще продолжали играть важную роль в урегулировании семейных отношений. Полигиния, принуждение девушек в раннем возрасте выйти замуж, калым, левират и другие семейные традиции, ущемляющие права женщин, продолжали устойчиво сохраняться. В Зилаирском кантоне «жизнь башкирской женщины часто тяжела. В большинстве неграмотная, она все еще раба своего мужа, все еще находится в экономической от него зависимости» [10 лет работы 1927: 63].

В Аргаяшском и Месягутовском кантонах в 1924 г. «очень молодых продают за престарелых... Жена умершего брата как приложение к имуществу переходит в жены к следующему брату» [НА РБ. Ф. 122. Оп. 3. Д. 44. Л. 133]. При этом мужчины имели право бросать своих жен. К примеру, в 1923 г. в Юрматинской волости около 100 женщин были оставлены своими мужьями [РГАСПИ. Ф. 17. Оп. 10. Д. 352. Л. 183об.].

В эти годы полигиния приобретала скрытый характер. Мужчины, зарегистрировав в органах ЗАГС один брак, другой заключали по нормам шариата [НА РБ. Ф. 122. Оп. 3. Д. 151. Л. 11об.].

В 1928 г. в Стерлитамакском кантоне многоженцы, имея по 3 жены, ловко выдавали своих жен за «домработниц» [Мужчина 1928: 4]. Латентная преступность порождала среди женской части населения скептическое отношение к преобразованиям в сфере семьи.

Традиционного патриархального уклада жизни в семье продолжали придерживаться даже в конце 1920-х гг. Так, полигиния и калым особенно были распространены в Зилаирском, Тамьян-Катайском, Месягутовском, Аргаяшском кантонах. Так, Зилаирский кантженотдел (с 1 декабря 1927 г. по 15 апреля 1928 г.) сообщал, что случаев многоженства и бытовых преступлений наблюдается много, а также обращал внимание на низкую степень правовой грамот- 
ности женского населения [НА РБ. Ф. 122. Оп. 7. Д. 126. Л. 49].

В 1928 г. в Темясовской волости было выявлено 229 случаев многоженства [НА РБ. Ф. Р-394. Оп. 2. Д. 602. Л. 144об., 145]. Полигиния наблюдалась даже среди членов партии. К примеру, 23-летний член ВКП(б) в Усмангалинской волости Тамьян-Катайского кантона, 39-летний кандидат в члены ВКП(б) в Зилаирском кантоне обвинялись в многоженстве [НА РБ. Ф. 122. Оп. 5 Д. 201. Л. 33об., 34].

Законодательство о браке и разводе вызвало сопротивление у части населения, в первую очередь религиозных деятелей. Заведующий женотделом Башобкома партии сообщала, что в Месягутовском кантоне «очень сильно влияние мулл, они работают против ЗАГСа, муллы учат продавать девчат, под влиянием мулл процветает многоженство» [НА РБ. Ф. 122. Оп. 5. Д. 201. Л. 12].

В 1929 г. в деревне Стерлибашево мулла вел активную работу против нововведений в области брака и семьи. В результате за его противозаконную деятельность ему было назначено наказание в виде условного осуждения [НА РБ. Ф. 122. Оп. 8. Д. 136. Л. 56].

Преобразования в брачно-семейных отношениях, начатые советской властью, наталкивались на сопротивление со стороны некоторых женщин, предпочитавших сохранять верность сложившимся традициям. Они соглашались быть второй или третьей женой, потому что экономически зависели от мужчин. При этом по статистике мужчин было меньше, чем женщин [Недолин 1924: 5]. Делегаты первой Всебашкирской беспартийной женской конференции в ноябре 1924 г. говорили, что после войны много одиноких женщин и вдов. Многие из них нуждались в материальной поддержке, поэтому соглашались на роль второй жены [Недолин 1924: 5].

В одной из волостей Аргаяшского кантона насчитывалось 500 вдов. Мужчины добивались, чтобы их жены на собраниях, конференциях требовали законного разрешения многоженства [Как сотни лет 1927: 3]. Возмущенные женщины решительно выступали против нового законодательства о браке и семье. На женской конференции в феврале 1927 г. в Дуван-Мечетлинской волости высказывались мнения о целесообразности сохранить калым [Сулейманова 2014: 136].
В 1928 г. на совещании волостных организаторов среди женщин Стерлитамакского кантона было сказано: «Работа по борьбе с бытовыми преступлениями ведется слабо, как в отношении разъяснения, а также и в части привлечения виновных к ответственности» [НА РБ. Ф.Р-394. Оп. 2. Д. 600. Л. 70].

Бытовая преступность принимала латентный характер. Факты полигинии, умыкания и уплата калыма часто скрывались. Очень редко женщины обращались с изнасилованием в судебно-следственные органы. Связано это с тем, что в эти годы не принято было предавать огласке факт насилия, потерпевшая всячески старалась скрыть информацию о случившемся [Намитоков 1929: 15].

В основном женщины обращались в суд с исковым заявлением, где просили взыскать алименты с бывшего мужа [НА РБ. Ф. 122. Оп. 5. Д. 202. Л. 22]. Однако находились среди женщин и те, которые не подавали заявления об алиментах в суд. Это происходило потому, что судебные разбирательства тянулись месяцами, а то и годами, по разным причинам значительное количество решений судов не исполнялось [НА РБ. Ф. 122. ОП. 7. Д. 126. Л. 6].

Нелегко доставались женщине свобода и равноправие. В 1928 г. в Больше-Окинской волости мужчина бросил свою бывшую супругу в реку Ай, чтобы не платить алименты. Еще более дикий случай произошел на почве ревности в Месягутово - муж зарезал жену. В деревне Арсланово Айлинской волости Месягутовского кантона мужчина убил свою жену за то, что, поскольку она была занята детьми, не досмотрела, как ушла корова со двора [НА РБ. Ф. 122. Оп. 7. Д. 126. Л. 2об., 3].

Тем не менее ключевые принципы семейного права постепенно начали входить в жизнь. Вмешательство государства в брачно-семейные отношения привело к тому, что привычный уклад жизни стал меняться. Семейные традиции (многоженство, левират, ранние браки, калым и др.) стали отмирать. Росла популярность новых законов среди женщин. Так, в отчете отдела по работе среди работниц и крестьянок Башобкома партии за ноябрь 1923 г. говорилось: «В отдел ежедневно приходят десятки женщин татаро-башкирок и русских за 
советами о разводах, детях и проч. Сидя в женотделах, особенно ярко замечаешь, как лопается и рассыпается изжившая себя мещанская семья» [НА РБ. Ф. 122. Оп. 2. Д. 39. Л. 47]. В докладе Аргаяшского кантженотдела за ноябрь-июнь 1926 г., направленном в областной женотдел, отмечалось, что женщины стали активно бороться с многоженством [НА РБ. Ф. 122. Оп. 5. Д. 204. Л. 33, 34].

К середине 1920-х гг. снизилось количество религиозных браков. Постепенно происходило становление и укрепление нового быта. Рождались новые праздники и традиции. Особое место получило проведение так называемых советских «красных свадеб» вместо никаха и венчания. В организации «красных свадеб» принимали участие местные партийные и советские руководители. Так, например, в деревне Мухамедьярово 1 октября 1927 г. провели «красную свадьбу» [Иванова 1927: 3]. В Стерлитамаке «красная свадьба» была открыта докладом о новом быте и «красных свадьбах». Во время бракосочетания молодожены торжественно заявили об отказе от традиций и религиозной жизни [Красную свадьбу 1928: 2].

Постепенно работа в отношении лиц, совершивших преступления, стала проводиться более упорядоченно и прозрачно. Повысилась эффективность деятельности правоохранительных органов в сфере борьбы с бытовой преступностью. В результате оправдательных приговоров стало меньше. В первой половине 1928 г., по сравнению с 1927 г., их доля снизилась с $60 \%$ до $19 \%$ [НА РБ. Ф. Р-394. Оп. 5. Д. 61. Л. 220].

Значительную работу по изменению статуса женщин в семье выполняли женотделы. Они вели активную работу среди женщин через делегатские собрания, конференции, съезды работниц и крестьянок и т. д. Национальные праздники, 8 марта использовались женотделами БАССР для агитационно-пропагандистской работы среди женского населения и разъяснения новых законов, прав женщин. В деятельности женотделов особое место занимало повышение правовой грамотности женского населения. Например, созданы секции при делегатских собраниях по правовой защите женщин. Coтрудники секции оказывали юридическую помощь в виде консультирования, составления документов правового характера, пред- ставления интересов женщин в суде и т. д. [НА РБ. Ф. 122. Оп. 3. Д. 28. Л. 32; НА РБ. Ф. 122. Оп. 5. Д. 202. Л. 22].

Другой формой работы женотделов являлась организация красных уголков, где женщины могли получить юридическую и психологическую помощь. В Тамьян-Тангаурской волости «каждый день по вечерам в красных уголках проводятся громкие читки материалов газет и журналов с последующей беседой по ним, а затем - игры и танцы под курай» [Сулейманова 2014: 154].

Весной 1924 г. при областном женотделе было создано бюро по оказанию правовой помощи. Газета «Власть труда» писала: «Учитывая все громадные задачи, стоящие перед женотделом в деле осуществления действительного равноправия женщин, Женотдел Башобкома организовал к международному дню работницы, бюро юридической помощи... которое должно дать новые знания... для борьбы до окончательного, фактического раскрепощения женщины» [Княжинская 1924: 3]. Позже они были открыты в кантонах республики. Так, в мае 1924 г. бюро было организовано в Зилаирском кантоне. Женщины обращались с целью получить юридическую поддержку. Для распространения правовых знаний среди женщин бюро юридической помощи проводило многочисленные публичные лекции и беседы. Основные вопросы - взыскание алиментов на детей, телесные повреждения и насилие над личностью [НА РБ. Ф. 122. Оп. 3. Д. 24. Л. 102; НА РБ. Ф. 122. Оп. 3. Д. 44. Л. 120; НА РБ. Ф. 122. Оп. 4. Д. 177. Л. 34]. Так, за два года работы сотрудники бюро юридической помощи дали свыше 3 тыс. правовых консультаций в письменной и устной форме. Отдельное внимание уделялось положению башкирской женщины [Сулейманова 2014: 145].

Работавшая в 1920-е гг. в Стерлитамаке, а потом в Уфе юрисконсульт Е. А. Княжинская вспоминала: «Мне запомнилась одна из наших посетительниц Ш. из отдаленной волости Уфимского кантона... Когда-то ее насильно выдали замуж, у нее было двое детей. Когда жизнь в семье стала невыносимой, она приехала в юрбюро... Мы узнали все подробности о жизни Ш. и помогли ей получить развод, обеспечить детей. С тех пор Ш. стала активисткой женотдела» [Женщины Башкирии 1968: 100]. 
Однако отделения бюро созданы были не везде. Это связано с тем, что не хватало специалистов в этой сфере. В частности, в Архангельской волости Уфимского кантона отмечалось, что «юридическое бюро в волости не имеется... нет работников» [НА РБ. Ф. 122. Оп. 4. Д. 175. Л. 7об.]. К сожалению, вскоре бюро юридической помощи было упразднено. Тем не менее на протяжении всего периода деятельности оно оказывало помощь женщинам в правовой области.

В эти годы в целях профилактики правонарушений в семейно-бытовой сфере и повышения доверия женщин к правоохранительным органам проводились открытые судебные заседания. Посещая гласные судебные разбирательства, женщины получали правовую информацию, ближе знакомились с деятельностью судов. Между тем уделялось недостаточное внимание этой форме правовой пропаганды среди женщин. Так, в 1928 г. всего в республике было проведено всего 57 открытых судебных заседаний [НА РБ. Ф. Р-394. Оп. 5. Д. 61. Л. 220].

Значительный вклад в дело борьбы за равноправие женщин внесла специальная комиссия по улучшению труда и быта женщин (КУТБ) при БЦИК, которая начала свою деятельность в мае 1927 г. [Сулейманова 2014: 156]. КУТБ уделяла особое внимание кооперативному строительству среди женщин. Была развернута работа по организации сети женских артелей по птицеводству, огородничеству, маслоделию и т. д. Кооперация способствовала улучшению экономической самостоятельности женского населения.

\section{Источники}

НА РБ - Национальный архив Республики Башкортостан.

РГАСПИ — Российский государственный архив социально-политической истории.

\section{Литература}

Барсов 1929 - Барсов Н. Н. Грамотность основных народностей БАССР // Хозяйство Башкирии. 1929. № 4-5. С. 200-221.

Бильшай 1959 - Бильмай В. Л. Решение женского вопроса в СССР. М.: Госполитиздат, 1959. $264 \mathrm{c}$.

Гниятуллина 2017 - Гниятуллина Г. Г. Государственная политика в отношении семьи в
Женщин стали вовлекать в общественно-политическую жизнь. В частности, в 1929 г. доля женщин в составе сельсоветов составляла $26 \%$, хотя в 1928 г. - $18 \%$. Если в 1928 г. председателями сельсоветов стали 9 женщин, то в 1929 г. - 114 [Женское движение 2008: 173].

\section{Заключение}

Октябрьская революция 1917 г., давшая толчок к проведению преобразований в семейно-брачных отношениях, утвердила новый правовой статус женщины в семье. В семейном законодательстве были определены основные принципы полного равноправия женщины и мужчины в семейно-брачных отношениях. В то же время в сознании части населения, особенно мужской, сохранялись пережитки старых взглядов, не были преодолены до конца имевшиеся трудности и недостатки, препятствовавшие изменению роли и места женщины в семье, повышению ее социального статуса. Сохранявшаяся неграмотность, особенно среди женского населения, не давала возможности решения за кратчайшие сроки такой важнейшей задачи, как улучшение положения женщины в семье, тому наглядным подтверждением является Башкирия. Так, в 1926 г. уровень грамотности среди женщин был в 2 раза ниже, чем среди мужчин. Процент грамотных среди русских женщин составлял $25 \%$, татарок - 22,5\%, башкирок - $14,4 \%$, чувашек - 11,9 \%, мариек - 5,7 \% [Барсов 1929: 220]. Несмотря на сложности, работа по улучшению положения женщин в семье дала положительные результаты.

\section{Sources}

National Archive of the Republic of Bashkortostan. Russian State Archive of Socio-Political History.

Башкирии в 1917-1941 гг.: автореф. дисс. ... канд. ист. наук. Екатеринбург, 2017. 30 с.

Градскова 2011 - Градскова Ю. В. «Раскрепощение националки» - социально-культурная политика советской власти в отношении женщин этнических меньшинств (на примере Волго-Уральского региона в 1920-е годы) // Журнал исследований социальной политики. 2011. Т. 9. № 1. С. 45-58. 
10 лет работы 1927 - 10 лет работы партии среди женщин Башкирии. Уфа: Отд. работниц и крестьянок Башкобкома ВКП(б), 1927. $183 \mathrm{c.}$

Еженедельник 1922 - Еженедельник советской юстиции. М.: НКЮ, 1922. № 11. 16 марта. C. 12 .

Женщины Башкирии 1968 - Женщины Башкирии. Уфа: Башкирское кн. изд-во, 1968. $452 \mathrm{c}$.

Женское движение 2008 - Женское движение в Башкортостане. 1900-1941: Сб. док. и мат-лов / Р. Н. Сулейманова (отв. ред.), Ш. Н. Исянгулов, Г. Ю. Султангужина. Уфа: Гилем, 2008. 272 с.

Журавлева, Мирошниченко 2017 - Журавлева В. А., Мирошничеко М. И. Брачное состояние городского населения Урала по материалам переписей 1923 и 1926 гг. // Уральский исторический вестник. 2017. № 4 (57). C. $68-72$.

Зуева 1925 - Зуева Е. Женщины в Советской России. М.: Госиздат, 1925. 25 с.

Иванова 1927 - Иванова Е. Горе башкирской женщины // Красная Башкирия. 1927. № 266 (2487). 20 ноября. С. 3.

Как сотни лет 1927 - Как сотни лет назад // Красная Башкирия. 1927. № 55 (2276). 8 марта. С. 3.

Княжинская 1924 - Княжинская Бюро юридической помощи женщине при женотделе обкома РКП(б) // Власть труда. 1924. № 57. 8 марта. С. 3.

Красную свадьбу 1928 - Красную свадьбу считаем открытой // Красная Башкирия. 1928. № 32 (2553). 7 февраля. С. 2.

Мирошниченко 2015а - Мирошниченко М. И. «Мусульманки интересуются советским законодательством гораздо больше, чем русские крестьянки»: мусульманки Урала и новая жизнь (1920-е годы - первая половина 1930-х годов) // Общество, гендер, история. Мат-лы VIII междунар. науч. конф. Липецк: Гравис, 2015. С. 41-43.

Мирошниченко 20156 - Мирошниченко М. И. Содержание первой советской гендерной модели в 1920-е гг. // Вестник ЮжноУральского государственного университета. Серия «Социально-гуманитарные науки». 2015. T. 15. № 1. С. 35-42.

Мужчина 1928 - Мужчина, который женился 18 раз... // Красная Башкирия. 1928. № 115 (2636). 18 мая. С. 4

Намитоков 1929 - Намитоков А. Пережитки родового быта и советский закон. М.; Л.: Госиздат, 1929.54 с.
Нафиков 1974 - Нафиков 3. 3. Социалистическая семья. Вопросы становления и развития (на примере Башкирской АССР). Уфа: Башкирск. кн. изд-во, 1974. 142 с.

Недолин 1924 - Недолин И. Прорыв в грядущее // Власть труда. 1924. № 259. 14 ноября. С. 5.

Нухрат 1932 - Нухрат А. И. Октябрь и женщина Востока. М.: Партиздат, 1932. 56 с.

Стина 1928 - Стина И. А. Башкирка. М.: Охрана материнства и младенчества, 1928.40 с.

Сулейманова 1998 - Сулейманова Р. Н. Женщины Башкортостана. Социальный облик (конец 50-х - начало 90-х годов). Уфа: Китап, 1998. 224 с.

Сулейманова 2008 - Сулейманова P. Н. Семейная политика РБ: состояние и задачи // Семья и семейные традиции у народов Башкортостана. Мат-лы Межрегиональной науч.-практ. конф. Уфа: ИИЯЛ УНЦ РАН, 2008. C. 118-121.

Сулейманова 2013 - Сулейманова Р. Н. Башкирская женщина раньше и теперь: традиции и новации в социальном статусе башкирской женщины в XX в. // Российская гендерная история с «юга» на «запад»: прошлое определяет настоящее. Мат-лы VI Междунар. науч. конф. Т. 2. Нальчик; М.: КБГУ им. Х. М. Бербекова, 2013. С. 84-86.

Сулейманова 2014 - Сулейманова Р. Н. Женщины в общественно-политической жизни Башкирии в XX веке: формы социальной активности и динамика социально-политической статуса. Уфа: Гилем, Башк. энцикл., 2014. $336 \mathrm{c}$

Сулейманова, Исянгулов 2020 - Сулейманова Р. Н., Исянгулов Ш. Н. Семья в условиях трансформации традиционного общества. Уфа: Мир печати, 2020. 155 с.

СУ РСФСР 1942 (1917а) - Собрание узаконений и распоряжений Рабочего и Крестьянского правительства Российской Советской Федеративной Социалистической Республики. Отдел первый. От 29 декабря 1917 г. М.: Управделами СНК СССР, 1942. 1483 с.

СУ РСФСР 1942 (1917б) - Собрание узаконений и распоряжений Рабочего и Крестьянского правительства Российской Советской Федеративной Социалистической Республики. Отдел первый. От 28 декабря 1917 г. М.: Управделами СНК СССР, 1942. 1483 с.

СУ РСФСР 1942 (1918) - Собрание узаконений и распоряжений Рабочего и Крестьянского правительства Российской Советской Федеративной Социалистической Республики. Отдел первый. От 22 октября 1918 г. М.: Управделами СНК СССР, 1942. 1483 с. 
Постановление ВЦИК 1924 - Постановление ВЦИК от 16.10.1924 «О дополнениях Уголовного Кодекса Р.С.Ф.С.Р. для автономных республик и областей» [электронный архив] // Акты с 1924 по 1934 гг. Библиотека нормативно-правовых актов СССР. Интернет-архив законодательства CCCP. URL: http:// www.libussr.ru/doc_ussr/ussr_2208.htm (дата обращения: 11.05.2013).

Постановление ВЦИК 1926 - Постановление ВЦИК от 19.11.1926 «О введении в действие Кодекса законов о браке, семье и опеке» [электронный архив] // Акты с 1924 по 1934 гг. Библиотека нормативно-правовых актов СССР. Интернет-архив законодательства CCCP. URL: http://www.libussr. ru/doc_ussr/ussr_3124.htm (дата обращения: 11.05. 2013$)$.

Постановление ВЦИК 1928 - Постановление ВЦИК от 06.04.1928«О дополнении Уголовного Кодекса РСФСР главой $\mathrm{X}$ «О преступлениях, составляющих пережитки родового быта», примечанием 2 статьи 66 Земельного Кодекса РСФСР, примечанием к статье 11 и примечанием 3 к статье 26 Уголовно-Процессуального кодекса РСФСР»

\section{References}

Barsov N. N. Literacy rates among ethnic groups of the Bashkir ASSR. Khozyaystvo Bashkirii. 1929. No. 4-5. Pp. 200-221. (In Russ.)

Bilshay V. L. Solving the Women's Question in the USSR. Moscow: Gospolitizdat, 1959. 264 p. (In Russ.)

Decree of the All-Russian Central Executive Committee of 16 October 1924 On Changes to the Criminal Code of the R.S.F.S.R. for Autonomous Republics and Oblasts. On: Legislative Acts, 1924 to 1934. Library of Soviet Laws and Regulations. Online archives of Soviet legislation. Available at: http://www.libussr.ru/doc ussr/ussr_2208.htm (accessed: May 11, 2013). (In Russ.)

Decree of the All-Russian Central Executive Committee of 19 November 1926 On Enforcement of the Code for Marriage, Family and Guardianship. On: Legislative Acts, 1924 to 1934. Library of Soviet Laws and Regulations. Online archives of Soviet legislation. Available at: http://www.libussr.ru/doc_ussr/ussr_3124.htm (accessed: May 11, 2013). (In Russ.)

Decree of the All-Russian Central Executive Committee of 6 April 1928 On Introduction of Section $\mathrm{X}$ to the Criminal Code of the R.S.F.S.R. (Crimes Resulting from Vestiges of Clan System), Note 2 to Article 66 of the Land Code of [электронный архив] // Акты с 1924 по 1934 гг. Библиотека нормативно-правовых актов СССР. Интернет-архив законодательства CCCP. URL: http:/www.libussr.ru/ doc_ussr/ussr_3363.htm (дата обращения: 11.05.2013).

Сытник 2006 - Сытник И. Г. Женский вопрос в политике государства и его решение на Южном Урале (1918-1930 гг.): автореф. дисс. ... канд. ист. наук. Оренбург, 2006. 26 с.

Сытник 2010 - Сытник И. Г. Религиозный аспект решения женского вопроса на Южном Урале в 1920-1930 гг. // Государственно-конфессиональные отношения: теория и практика. Мат-лы Междунар. науч.-практ. конф. Оренбург: ООО «Агентство «Пресса», 2010. C. 311-317.

Хилажева 2010 - Хилажева Г. Ф. Гендерные стереотипы и нормы поведения в современном башкирском обществе // Проблемы востоковедения. 2010. № 1(47). С. 27-32.

Хилажева 2015 - Хилажева Г. Ф. Насилие в семье как социальная проблема современного общества // Социологические исследования. 2015. № 8. С. 61-65.

the R.S.F.S.R., a Note to Article 11 and Note 3 to Article 26 of the Criminal Procedure Code of the R.S.F.S.R. On: Legislative Acts, 1924 to 1934. Library of Soviet Laws and Regulations. Online archives of Soviet legislation. Available at: http://www.libussr.ru/doc_ussr/ussr_3363. htm (accessed: May 11, 2013). (In Russ.)

Ezhenedel'nik sovetskoy yustitsii (The Weekly of Soviet Justice). 1922, March 16. No. 11. P. 12. (In Russ.)

Gniyatullina G. G. State Family Policy in Bashkiria, 1917-1941. Cand. Sc (history) thesis abstract. Yekaterinburg, 2017. 30 p. (In Russ.)

Gradskova Yu. V. 'Emancipation of non-Russian women' - Soviet sociocultural policy towards ethnic minority women: a case study of the Volga-Ural region, 1920s. The Journal of Social Policy Studies. 2011. Vol. 9. No. 1. Pp. 45-58. (In Russ.)

Ivanova E. The grief of Bashkir women. Krasnaya Bashkiriya. 1927, November 20. No. 266 (2487). P. 3. (In Russ.)

Khilazheva G. F. Domestic violence as a social problem of contemporary society. Sotsiologicheskie issledovaniya. 2015. No. 8. Pp. 61-65. (In Russ.)

Khilazheva G. F. Gender stereotypes and norms of behavior in modern Bashkir society. The Problems of Oriental Studies. 2010. No. 1(47). Pp. 27-32. (In Russ.) 
Khisamitdinova F. G., Suleymanova R. N. et al. (eds.), Isyangulov Sh. N., Sultanguzhina G. Yu. (comps.) The Women's Movement in Bashkortostan, 1900-1941: Collected Documents and Materials. Ufa: Gilem, 2008. 272 p. (In Russ.)

Knyazhinskaya. Women's Department of the RK$\mathrm{P}(\mathrm{b})$ and its Legal Assistance Bureau. Vlast' truda. 1924, March 8. No. 57. P. 3. (In Russ.)

Like hundreds of years ago. Krasnaya Bashkiriya. 1927, March 8. No. 55 (2276). P. 3. (In Russ.)

Man who was married for 18 times... Krasnaya Bashkiriya. 1928, May 18. No. 115 (2636). P. 4. (In Russ.)

Miroshnichenko M. I. 'The interest in Soviet legislation shown by Muslim women is far deeper than that of Russian female peasants': Muslim women of the Urals and the new life, 1920s mid-1930s. In: Society, Gender, History. Conference proceedings. Lipetsk: Gravis, 2015. Pp. 41-43. (In Russ.)

Miroshnichenko M. I. Contents of the first Soviet gender patterns in 1920-s. Bulletin of the South Ural State University. Series 'Social Sciences and the Humanities'. 2015. Vol. 15. No. 1. Pp. 35-42. (In Russ.)

Nafikov Z. Z. Socialist Family, Issues of Formation and Development: A Case Study of the Bashkir ASSR. Ufa: Bashkir Book Publ., 1974. P. 142. (In Russ.)

Namitokov A. Vestiges of Clan System and Soviet Law. Moscow; Leningrad: Gosizdat, 1929. 54 p. (In Russ.)

Nedolin I. Breakthrough into future. Vlast' truda. 1924, November 14. No. 259. P. 5. (In Russ.)

Nukhrat A. I. The October Revolution and Oriental Woman. Moscow: Partizdat, 1932. 56 p. (In Russ.)

Red wedding considered open. Krasnaya Bashkiriya. 1928, February 7. No. 32 (2553). P. 2. (In Russ.)

Stina I. A. Bashkir Woman. Moscow: Okhrana Materinstva i Mladenchestva, 1928. 40 p. (In Russ.)

Suleimanova R. N. Bashkir woman in past and present: traditions and innovations in social status throughout the $20^{\text {th }}$ century. In: Russian Gender History from the 'South' towards the 'West': How the Past Predetermines the Present. Conference proceedings. Vol. 2. Nalchik; Moscow: Berbekov Kabardino-Balkarian State University, 2013. Pp. 84-86. (In Russ.)

Suleimanova R. N. Family policy in the Republic of Bashkortostan: current state and objectives. In: Family and Family Traditions among Peoples of Bashkortostan. Conference proceedings.
Ufa: Institute of History, Language and Literature (Ural Research Centre of RAS), 2008. Pp. 118-121. (In Russ.)

Suleimanova R. N. Women in Sociopolitical Life of $20^{\text {th }}$-Century Bashkiria: Social Activity Patterns and Dynamics of Sociopolitical Status. Ufa: Gilem, Bashkirskaya Entsiklopediya, 2014. 336 p. (In Russ.)

Suleimanova R. N. Women of Bashkortostan: Social Appearances, Late 1950s - Early 1990s. Ufa: Kitap, 1998. 224 p. (In Russ.)

Suleimanova R. N., Isyangulov Sh. N. Family in the Context of Transformed Traditional Society. Ufa: Mir Pechati, 2020. 155 p. (In Russ.)

Sytnik I. G. Solving the women's question in the Southern Urals, 1920s-1930s: religious aspect revisited. In: State and Confessional Relations in Theory and Practice. Conference proceedings. Orenburg: Pressa, 2010. Pp. 311-317. (In Russ.)

Sytnik I. G. The Women's Question in State Policies and Its Solution in the Southern Urals, 1918-1930s. Cand. Sc. (history) thesis abstract. Orenburg, 2006. 26 p. (In Russ.)

Ten Years of the Party's Work among Bashkiria's Women. Ufa: Department of Female Workers and Peasants (VKP(b) Bashkiria Regional Committee), 1927. 183 p. (In Russ.)

Women of Bashkiria. Ufa: Bashkir Book Publ., 1968. 452 p. (In Russ.)

Workers and Peasants Government of the Russian Soviet Federative Socialist Republic: Collected Laws and Decrees. December 29, 1917. Part One. Moscow: Council of People's Commissars of the Soviet Union (Executive Office), 1942. 1483 p. (In Russ.)

Workers and Peasants Government of the Russian Soviet Federative Socialist Republic: Collected Laws and Decrees. December 28, 1917. Part One. Moscow: Council of People's Commissars of the Soviet Union (Executive Office), 1942. 1483 p. (In Russ.)

Workers and Peasants Government of the Russian Soviet Federative Socialist Republic: Collected Laws and Decrees. October 22, 1918. Part One. Moscow: Council of People's Commissars of the Soviet Union (Executive Office), 1942. 1483 p. (In Russ.)

Zhuravleva V. A., Miroshnicheko M. I. Marital status of the urban population of the Ural according to the 1923 and 1926 censuses data. Ural Historical Journal. 2017. No. 4(57). Pp. 68-72. (In Russ.)

Zueva E. Women in Soviet Russia. Moscow: Gosizdat, 1925. 25 p. (In Russ.) 